\title{
Protective immunity in mice vaccinated with a novel elastase- 1 significantly decreases Trichinella spiralis fecundity and infection
}

\author{
Xin Zhuo Zhang ${ }^{1}$, Xiang Yuan Sun ${ }^{2}$, Ying Bai ${ }^{2}$, Yan Yan Song ${ }^{2}$, Chen Xi Hu${ }^{2}$, Xiangrui $\mathrm{Li}^{1 *}$, Jing Cui ${ }^{2^{*}}$ \\ and Zhong Quan Wang ${ }^{2^{*}}$
}

\begin{abstract}
Trichinella spiralis is an important foodborne parasitic nematode that represents an enormous threat to the food safety of pork meat. The development of a preventive vaccine is valuable for the prevention and control of Trichinella infection in domestic pigs to ensure pork safety. Elastase is a trypsin-like serine protease that hydrolyzes the host's diverse tissue components and participates in parasite penetration, and it might be a novel vaccine target molecule. The aim of this study was to assess the protective immunity produced by vaccination with a novel Trichinella spiralis elastase-1 (TsE) in a mouse model. The results demonstrate that subcutaneous vaccination of mice with rTsE elicited a systemic humoral response (high levels of serum IgG and subclass IgG1/lgG2a and IgA) and significant local enteral mucosal slgA responses. Anti-rTsE IgG recognized the native TsE at the cuticle, stichosome of intestinal infective larvae and adult worm (AW), and intrauterine embryos of female AW. The rTsE vaccination also produced a systemic and local mixed Th1/Th2 response, as demonstrated by clear elevation levels of Th1 cytokines (IFN- $\gamma$, IL-2) and Th2 cytokines (IL4, IL-10) after spleen, mesenteric lymph node and Peyer's patch cells from immunized mice were stimulated with rTsE. The immunized mice exhibited a 52.19\% reduction in enteral AW and a $64.06 \%$ reduction in muscle larvae after challenge infection. The immune response triggered by $\mathrm{rTSE}$ vaccination protected enteral mucosa from larval intrusion, suppressed larval development and reduced female fecundity. The results indicate that TsE may represent a novel target molecule for anti-T. spiralis vaccines.
\end{abstract}

\section{Introduction}

Trichinella spiralis is an important foodborne parasitic nematode that is distributed worldwide in over 150 kinds of mammals [1]. Human T. spiralis infection principally results from ingestion of the encapsulated infective larvae present in raw or uncooked meat and meat products. Domestic pigs are the crucial infection source of human T. spiralis infection in China and other developing

\footnotetext{
*Correspondence: lixiangrui@njau.edu.cn; cuij@zzu.edu.cn; wangzq2015@126.com

${ }^{1}$ College of Veterinary Medicine, Nanjing Agricultural University, Nanjing 210095, China

${ }^{2}$ Department of Parasitology, Medical College, Zhengzhou University, Zhengzhou 450052, China
}

countries [2-5]. From 2004 to 2009, 14 trichinellosis outbreaks owing to infected domestic pork and wild boar meat were reported in the Chinese mainland [6]. As a considerable quantity of pork is consumed around the world, T. spiralis infection in domestic pigs represents a severe risk to public health and a notable hazard to pork meat safety $[5,7]$. Therefore, it is necessary to develop a preventive vaccine to block Trichinella infection in domestic swine and transmission from swine to humans [8-10].

After the infected meat is ingested, T. spiralis muscle larvae (ML) are released from their capsules with the aid of gastric fluid digestion and develop into intestinal infective larvae (IIL) after being exposed to enteral contents or bile $[11,12]$. The IIL intrudes the enteral epithelium 
and grows to adult worm (AW) stages after molting four times. The adult males and females mate, and pregnant females yield the next generation of larvae (newborn larvae, NBL). The NBL enters the blood circulation, invades the host's striated muscles and forms encapsulated larvae to complete its lifecycle [13]. The intestinal epithelium is the primary native protective screen against $T$. spiralis intrusion and the principal interaction place of the host and the parasite [14, 15], but the mechanism of intrusion of the intestinal epithelium by $T$. spiralis larvae has not been fully elucidated $[16,17]$. The excretion/secretion (ES) products of T. spiralis IIL larvae, which are first exposed to intestinal epithelium cells (IECs), are likely to have a crucial effect on larval intrusion and elicit the enteral mucosal response $[18,19]$. In our previous studies, some serine proteases have been identified in T. spiralis IIL and AW ES products by immunoproteomics [20, $21]$. When T. spiralis IIL larvae were cocultured with an IEC monolayer, the IIL intruded the monolayer and generated secretory serine proteases and entered the IEC $[22,23]$. Furthermore, the expression levels of serine proteases at the IIL stage were evidently higher than those at the ML stage [24]. As a result, T. spiralis serine proteases might facilitate larval intrusion into the enteral epithelium and aid the nematode in establishing intestinal infection [25-27]. Therefore, serine proteases are promising candidate vaccine targets against $T$. spiralis enteral phase worms.

In this study, a novel elastase gene of T. spiralis (TsE, GenBank accession no. EFV56917.1) was retrieved from the draft genome of T. spiralis [28]. The elastase, which belongs to the serine protease family, was cloned, expressed and purified in our laboratory. Bioinformatic analysis results revealed that the complete TsE cDNA sequence was 1350 bp encoding 449 amino acids with a $47.3 \mathrm{kDa}$. The TsE carried a functional domain at 38-314 aa. TsE was highly expressed at the T. spiralis ML and IIL worm phases [29]. Recombinant TsE (rTsE) promoted larval intrusion into the IEC monolayer, whereas antirTsE serum and RNAi suppressed larval invasion. The objective of this study was to assess the immune protection produced by rTsE immunization in a model of $\mathrm{BALB} / \mathrm{c}$ mice.

Although complete Freund's adjuvant (CFA) is one of the most commonly used adjuvants for experimental antibody generation, its clinical application has been limited due to the side effects and local lesions that it causes. The series of Montanide incomplete Seppic adjuvants (ISAs) are new-generation adjuvants of water-inoil emulsions (w/o) after being mixed with antigens, which have favorable adjuvant characteristics for eliciting a long-term and strong immune response [30]. The ISA contains an injectable pharmaceutical mineral oil and a refined emulsifier originating from mannitol, purified vegetable oleic acid, and copolymers of methacrylic acid. Furthermore, subcutaneous inoculation has the advantages of easy injection, rapid absorption, and high immune efficacy. Therefore, BALB/c mice were immunized by subcutaneous inoculation with the rTsE formulated with ISA201 adjuvant of Montanide ISA series in the present study.

\section{Materials and methods}

\section{Parasites and experimental animals}

The T. spiralis strain (ISS534) utilized in the present study was collected from a domestic pig in mainland China and passaged in our department [31]. Four-week-old female $\mathrm{BALB} / \mathrm{c}$ mice were purchased from the Experimental Animal Center of Henan Province (Zhengzhou, China) and raised in specific pathogen-free conditions of individual ventilated cages (IVCs, Suzhou, China) [32].

\section{Preparation of rTsE}

The complete TsE gene was cloned, and the recombinant expression plasmid $\mathrm{pQE}-80 \mathrm{~L} / \mathrm{TsE}$ was transformed into Escherichia coli BL21 (Novagen, USA). Expression of $\mathrm{rTsE}$ protein was induced using $1 \mathrm{mM}$ IPTG at $37^{\circ} \mathrm{C}$ for $6 \mathrm{~h}$ [33]. rTsE was purified using Ni-NTA-Sefinose resin (Sangon Biotech, China) in our laboratory and identified by anti-rTsE serum and T. spiralis-infected mouse sera by Western blot analysis.

\section{Immunization of mice}

A total of 210 mice were randomly divided into three groups (70 animals per group). Each mouse was subcutaneously immunized by using $20 \mu \mathrm{g}$ rTsE emulsified with Montanide ISA 201 adjuvant (Seppic, France) and boosted three times with rTsE with ISA 201 at a 4-week interval for the first immunization and at a two-week interval for the second and third boosts. The control group was administered ISA 201 adjuvant or PBS alone according to the same protocol as the immunization group $[9,30]$. Approximately $100 \mu \mathrm{L}$ of blood was taken from each mouse tail prior to immunization and at 4, 6, 8 and 10 weeks after immunization. Individual serum sample was kept at $-80^{\circ} \mathrm{C}$ until use [34].

\section{Detection of antibody responses to $\mathrm{rTsE}$}

Serum levels of anti-rTsE antibodies (total IgG, IgG1, IgG2a, and IgA) in all vaccinated mice were tested by ELISA with rTsE $[35,36]$. Briefly, the ELISA plate was coated using $1 \mu \mathrm{g} / \mathrm{mL}$ rTsE for total IgG and $2 \mu \mathrm{g} / \mathrm{mL}$ rTsE for IgG1, IgG2a and IgA at $37{ }^{\circ} \mathrm{C}$ for $2 \mathrm{~h}$. Skimmed milk at a $5 \%$ concentration was used for blocking at $37{ }^{\circ} \mathrm{C}$ for $1 \mathrm{~h}$. Different dilutions of mouse sera $(1: 100$ for detecting IgG, IgG1 and IgG2a; 1:50 for detecting IgA) 
were added and incubated at $37{ }^{\circ} \mathrm{C}$ for $2 \mathrm{~h}$. Following washes with TBS-0.5\% Tween 20 (TBST), 1:10 000 dilutions of HRP-conjugated anti-mouse IgG, IgG1 or IgG2a, and 1:5000 dilutions of HRP-conjugated anti-mouse IgA were added and incubated for $1 \mathrm{~h}$ at $37{ }^{\circ} \mathrm{C}$ [37]. Plates were developed with o-phenylenediamine dihydrochloride (OPD; Sigma-Aldrich) plus $\mathrm{H}_{2} \mathrm{O}_{2}$, and the reaction was terminated by using $2 \mathrm{M} \mathrm{H}_{2} \mathrm{SO}_{4}$. The absorbance at $492 \mathrm{~nm}$ was assayed using a microplate reader (Tecan, Schweiz, Switzerland) [38, 39].

\section{Assessment of total IgA and secretory anti-TsE IgA in intestinal washes}

To measure total and TsE-specific secretory IgA (sIgA) in enteral fluid, intestinal washing was prepared [10, 40]. Briefly, a $20-\mathrm{cm}$-long small intestine segment was cut, and the enteral interior was eluted three times using $1 \mathrm{~mL}$ of PBS with $1 \%$ protease inhibitor (Sangon Biotech, Shanghai, China). The flushing fluid was collected and centrifuged at $10,000 \mathrm{~g}$ for $5 \mathrm{~min}$, and the supernatants were harvested [31]. Total intestinal sIgA was determined by a conventional sandwich ELISA as previously described [41]. TsE-specific sIgA was measured by a routine indirect ELISA with $1 \mu \mathrm{g} / \mathrm{mL}$ of $\mathrm{rTsE}$ as described [42, 43]. The coloration with OPD and assay of the absorbance at $492 \mathrm{~nm}$ were carried out as described before [44].

\section{Recognition of native TsE in worms at different $T$. spiralis stages by immunofluorescence test (IFT)}

The identification of native TsE in T. spiralis diverse lifecycle stage worms was performed using an immunofluorescence test (IFT) with worm cross-sections [45, 46]. The ML were obtained by artificial digestion of skeletal muscles from experimentally $T$. spiralis-infected mice at 42 days post-infection (dpi) [47]. IILs were recovered from the infected mouse intestine at $6 \mathrm{hpi}$ [24], and adult worms (AWs) were collected from the intestine at $3 \mathrm{dpi}$ [48]. The worms were embedded in paraffin, $3-\mu \mathrm{m}$-thick cross-sections were prepared, and IFT was carried out as previously reported $[32,49]$. The sections were sealed at $37{ }^{\circ} \mathrm{C}$ for $1 \mathrm{~h}$ with $5 \%$ normal goat serum and probed by a 1:10 dilution of three different sera (anti-rTsE serum, infection serum and normal serum) at $37^{\circ} \mathrm{C}$ for $1 \mathrm{~h}$. Following three washes with $\mathrm{PBS}$, the worm cross-section was stained at $37^{\circ} \mathrm{C}$ for $1 \mathrm{~h}$ with FITC-anti-mouse IgG conjugate (1:100; Santa Cruz, USA) and observed under a fluorescence microscope (Olympus, Japan) [50, 51].

\section{Cytokine determination}

To ascertain the TsE-specific cellular immunological response, the spleens, mesenteric lymph nodes (MLNs) and Peyer's patches (PPs) were recovered from vaccinated mice at weeks $0,4,6,8$ and 10 following immunization. Spleen, MLN and PP were ground with complete RPMI-1640 medium (Gibco, Auckland, New Zealand), the pellets were obtained after centrifugation at $300 \mathrm{~g}$ for $5 \mathrm{~min}$, and the cells were separated as reported before $[45,52]$. The cellular density was set to $2 \times 10^{6}$ cells $/ \mathrm{mL}$ in RPMI-1640 medium supplemented with $5 \%$ fetal bovine serum (FBS; Gibco), penicillin $(100 \mathrm{U} / \mathrm{mL})$ and streptomycin $(100 \mu \mathrm{g} / \mathrm{mL})$. The cells were stimulated using $10 \mu \mathrm{g} / \mathrm{mL}$ rTsE for $72 \mathrm{~h}$, the supernatant was harvested, and four cytokines (IL-2, IL-4, IL-10 and IFN- $\gamma$ ) were determined by sandwich ELISA $[9,53]$. The concentrations of four cytokines were presented as picograms per milliliter $(\mathrm{pg} / \mathrm{mL})$.

\section{Oral larva challenge infection and assessment of immune protection}

To appraise the immune protection induced by immunization with $\mathrm{rTsE}$, each vaccinated mouse was orally inoculated using $300 \mathrm{~T}$. spiralis infective larvae 2 weeks after the fourth vaccination. The AWs were recovered from the small intestines of ten mice of each group at 7 dpi $[54,55]$. The ML were collected from an additional ten mice at $42 \mathrm{dpi}$ by digesting the infected mouse striated muscles [56]. Moreover, the length of adult females was measured by microscopy. Adult female reproduction capacity was also determined after being cultivated in RPMI-1640 culture medium for $72 \mathrm{~h}$, the NBL yielded by each adult female was accounted for, and their length was examined [57]. The effectiveness of immune protection produced by TsE immunization was ascertained as the parasite reduction of enteral adult worms and larvae per gram (lpg) of striated muscles of immunized mice in comparison with those of the PBS group [58-60].

\section{Antibody-dependent cell-mediated cytotoxicity (ADCC) assay}

In this study, anti-rTsE antibody cytotoxicity on the NBL was also conducted as previously reported $[39,61]$. Forty NBLs were cocultivated for $48 \mathrm{~h}$ at $37{ }^{\circ} \mathrm{C}$ with $2 \times 10^{5}$ mouse peritoneal exudate cells (PECs) in 96-well plates in RPMI-1640 medium containing anti-rTsE serum, infection serum and preimmune serum. Each assay was performed in triplicate. The larval viability after ADCC treatment was ascertained according to larval morphological characteristics and activity by microscopy. The live NBL were mobile and exhibited wriggling, whereas the dead worms were straight and immobile. The cytotoxicity was assessed as the percent of the dead worms to the total worms observed in each assay [50]. 


\section{Statistical analysis}

Statistical analysis of all the data was conducted by using SPSS for Windows, version 20.0. The data are represented as the mean \pm standard deviation. Differences among diverse groups were analyzed by one-way ANOVA. A Chi square test was applied to analyze the relationship between ADCC cytotoxicity and serum dilution/culture time. $P<0.05$ was considered to be significant.

\section{Results}

\section{Humoral immunological response to rTsE immunization}

The mice were vaccinated using $\mathrm{rTsE}$ four times, and the serum anti-rTsE antibody IgG titer at two weeks after the fourth vaccination was measured by ELISA. The antirTsE IgG level in mice vaccinated with rTsE was prominently elevated, and the mean antibody titer reached 1:10 000 after the fourth vaccination (Figure 1), indicating that $\mathrm{rTsE}$ was a strong immunogenic protein. However, no anti-rTsE IgG antibody responses were detected in mice inoculated with ISA 201 alone or PBS (Figure 2A). The IgG1 level at 4, 6, 8 and 10 weeks post-vaccination was obviously higher than the IgG2a level (Figures 2C, D) (week 4: $\mathrm{t}=2.564, P=0.027$; week 6: $\mathrm{t}=17.553$, $P<0.0001$; week 8: $\mathrm{t}=33.294, P<0.0001$; week 10 : $\mathrm{t}=26.911, P<0.0001)$, suggesting that the dominant IgG subclass elicited by rTsE immunization was IgG1. Nonetheless, the IgA response was also triggered after immunization (Figure $2 \mathrm{~B}$ ).

\section{Intestinal mucosal immune response elicited by TsE immunization}

To assess the enteral mucosal sIgA response to $\mathrm{rTsE}$ immunization, total sIgA and TsE-specific sIgA were

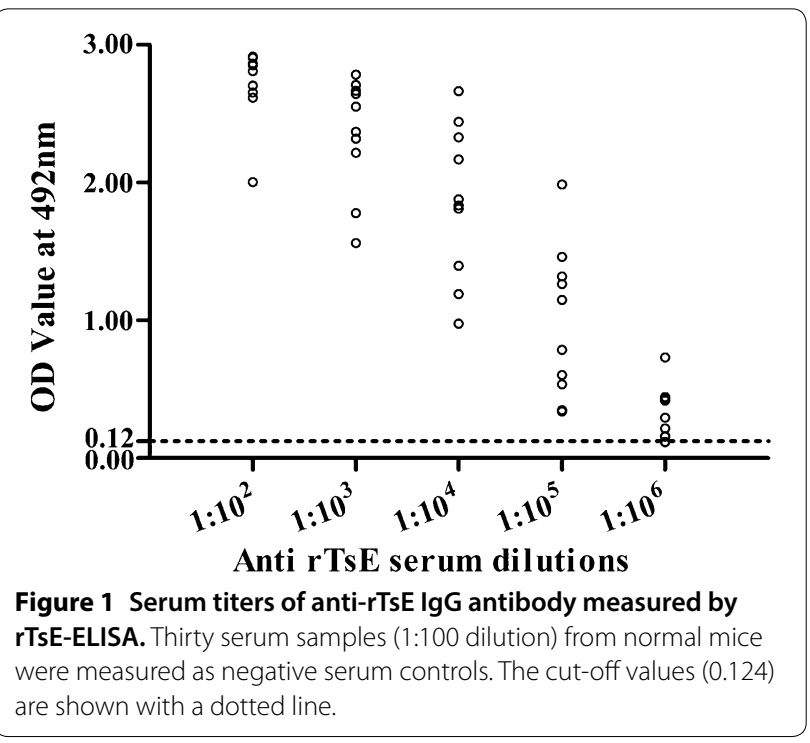

determined using ELISA. The results revealed that the total sIgA level was conspicuously elevated in rTsEimmunized mice compared to mice inoculated with only ISA 201 adjuvant (week 4: $\mathrm{t}=44.572, P<0.0001$; week 6: $\mathrm{t}=61.563, P<0.0001$; week $8: \mathrm{t}=28.126, P<0.0001$; week $10: \mathrm{t}=13.864, P<0.0001$ ) (Figure 3A). The levels of intestinal-specific anti-TsE sIgA in mice immunized with rTsE were also distinctly higher than those of mice injected with ISA 201 alone (week 4: $\mathrm{t}=17.837, P<0.0001$; week 6: $\mathrm{t}=22.582, P<0.0001$; week $8: \mathrm{t}=33.342, P<0.0001$; week 10: $\mathrm{t}=12.691, P<0.0001$ ) (Figure $3 \mathrm{~B}$ ). No rTsEspecific mucosal sIgA was detected in mice injected with only PBS and ISA 201.

\section{Recognition of native TsE at diverse stage worms by IFT}

The IFT results showed that anti-rTsE serum recognized the natural TsE on worm cross-sections, green fluorescence was primarily at the cuticle, at the stichosome of IIL and AW, and at intrauterine embryos of female adult worms (Figure 4). Serum from mice inoculated with only ISA 201 adjuvant and PBS did not identify any worm tissue component of the parasitic nematode.

\section{Cytokine response to rTsE vaccination}

To assess the cytokine response elicited by rTsE vaccination, spleen, MLN and PP cells obtained from vaccinated mice were cultivated under rTsE stimulation. Supernatants were collected, and cytokine concentrations were measured using sandwich ELISA. The levels of Th1 (IFN$\gamma$ ) and Th2 cytokines (IL-4, IL-10) clearly increased after the third immunization with rTsE compared with the ISA201 and PBS groups $(P<0.0001)$ (Figure 5). Moreover, the IL-2 levels were elevated earlier than those of the other three cytokines. Our results demonstrated that rTsE vaccination triggered mixed Th1/Th2 responses on the basis of specific IgG subclass responses and cytokine generation, suggesting that subcutaneous vaccination with $\mathrm{rTsE}$ triggered both systemic (spleen) and enteral mucosal local (MLN and PP) cellular immunological responses.

\section{Immune protection produced by rTsE immunization against $T$. spirali larval infection}

Compared with PBS control mice, the rTsE-immunized mice showed a $52.19 \%$ decrease in enteral adults at $7 \mathrm{dpi}$ (Figure 6A) and a 64.06\% decrease in muscle larvae at 42 dpi (Figure 6B) after oral infection with $300 \mathrm{~T}$. spiralis muscle larvae $\left(F_{\text {adults }}=11.330, P<0.0001 ; F_{\text {larvae }}=11.107\right.$, $P<0.0001$ ).

Additionally, the length of female adults of rTsE-immunized mice at $7 \mathrm{dpi}$ had no statistically obvious difference compared with those from the ISA201 and PBS groups $(F=0.89, P>0.05)$. However, the production of NBL 

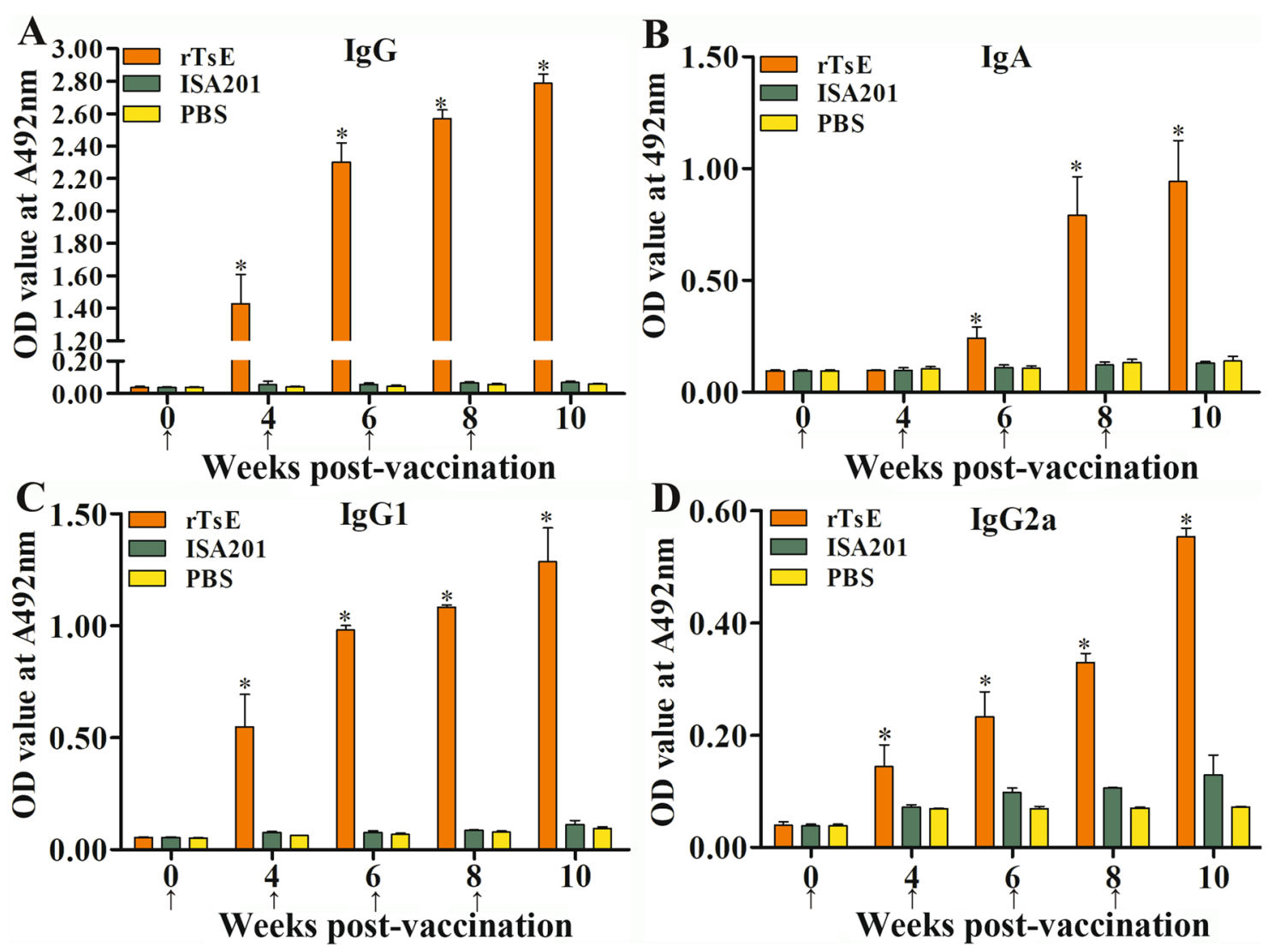

Figure 2 Specific anti-rTsE antibody responses in mice vaccinated with rTsE. Specific total lgG response was determined in rTsE-vaccinated mice or control mice (ISA 201 adjuvant and PBS) at various time intervals post-vaccination (A). B Specific IgA levels in vaccinated mice. rTsE-specific $\operatorname{lgG1}(\mathbf{C})$ and lgG2a (D) subclass responses were also detected at various times post-vaccination. The OD value from each group is presented as the mean \pm SD of antibody levels $(n=10)$. The vaccination time is indicated as an arrow $(\uparrow)$. ${ }^{*} P<0.05$ compared with the ISA 201 adjuvant or PBS group.
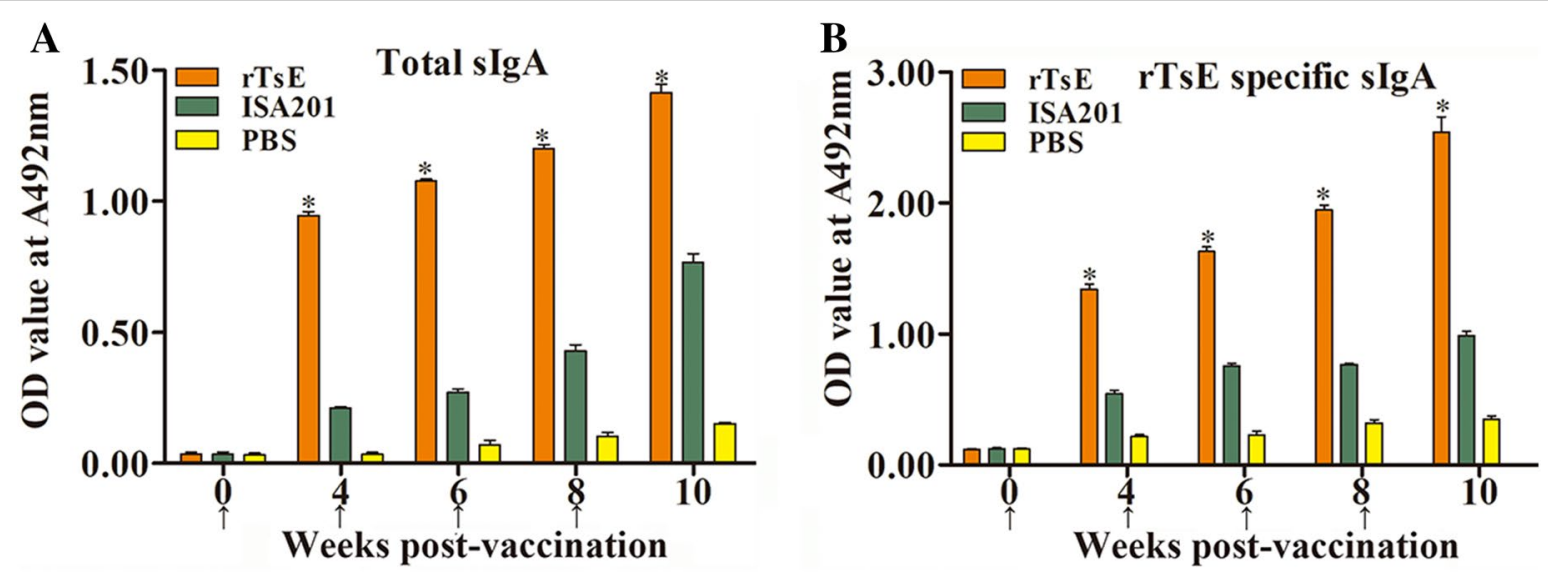

Figure 3 Levels of total intestinal slgA (A) and TsE-specific slgA (B) in intestinal washing of vaccinated mice. The data are shown as the mean OD values \pm SD for 10 mice per group. TsE-specific slgA was undetectable in mice injected with only ISA 201 or PBS. The vaccination time is indicated as an arrow $(\uparrow) .{ }^{*} P<0.0001$ compared with PBS and ISA 201 adjuvant group. 


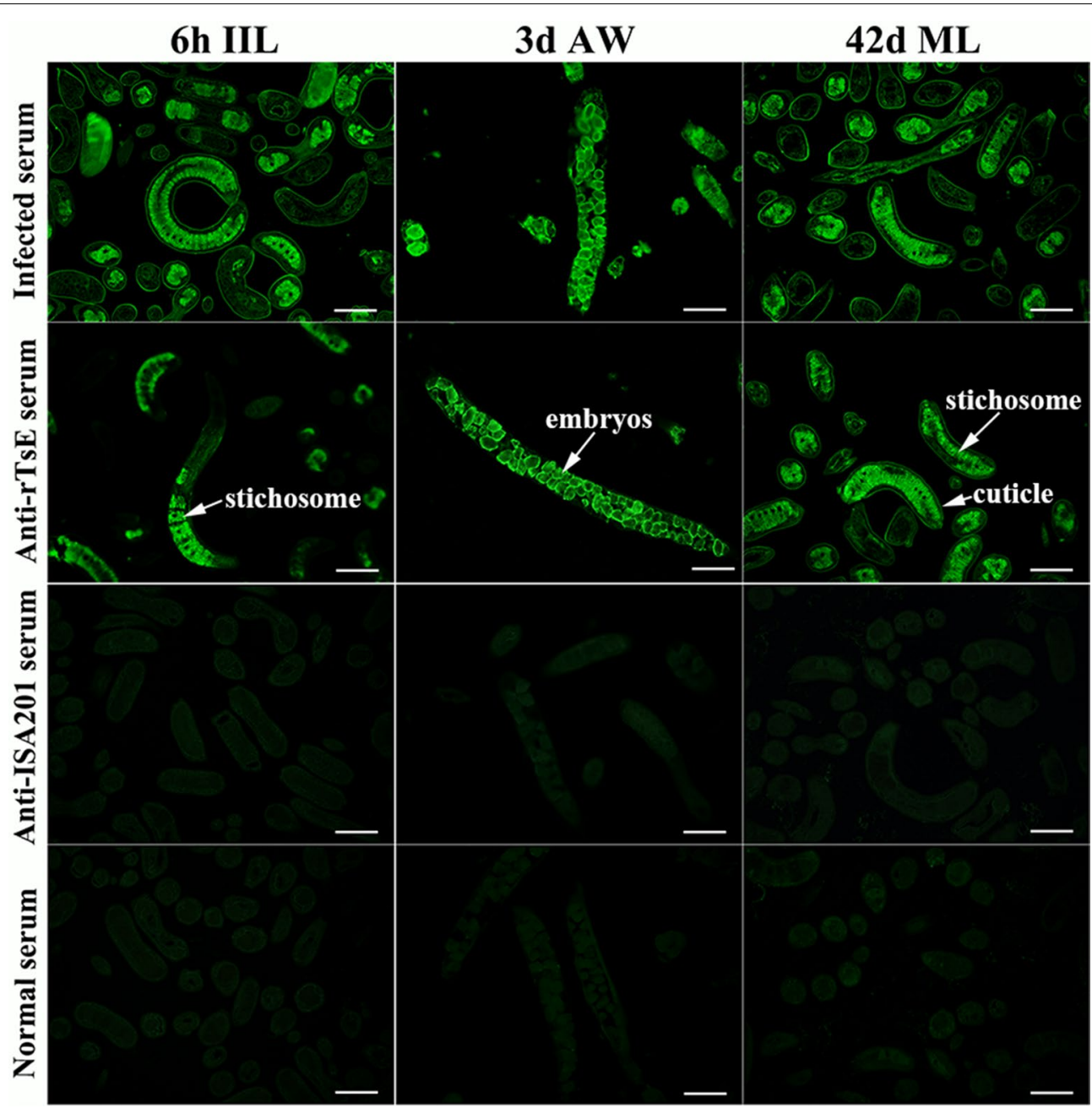

Figure 4 Recognition of native TsE at diverse T. spiralis stage worms by IFT with serum from mice vaccinated by rTsE, alone ISA 201 adjuvant or PBS. Green fluorescence was located at the cuticle, stichosome of IIL and AW, and intrauterine embryos of female AW of this parasite. The serum of mice inoculated using ISA 201 adjuvant alone and PBS did not identify any worm tissue components of the parasites. Scale bar $=100 \mu \mathrm{m}$.

yielded in vitro for $72 \mathrm{~h}$ by each female adult from rTsEimmunized mice was evidently inferior to that of the ISA201 and PBS groups (Figure 7) $(F=7.110, P<0.01)$. The results indicated that immunization of mice with rTsE decreased the enteral adult burden and reduced adult female fecundity, thereby relieving the larval burden in skeletal muscles of immunized mice.

\section{Destruction of NBL by ADCC}

The results of the ADCC test revealed that after being cultivated at $37{ }^{\circ} \mathrm{C}$ for $48 \mathrm{~h}$, anti-rTsE serum mediated the attachment and destruction of the PECs to the NBL (Figure 8). While 1:10, 1:50 and 1:100 dilutions of antirTsE sera were supplemented, the ADCC led to a significant death of the NBL $(38.45 \%, 24.15 \%$ and $23.76 \%$ cytotoxicity) compared to the NBL cocultivated in preimmune serum $(17.00 \%, 12.18 \%$ and $11.77 \%)(\mathrm{t}=8.280$, $\left.P_{1: 10}<0.01 ; \mathrm{t}=3.102 P_{1: 50}<0.05 ; \mathrm{t}=5.200, P_{1: 100}<0.017\right)$. The cytotoxicity was anti-rTsE antibody dose dependent $(\mathrm{r}=0.898, P<0.0001)$, and the cytotoxicity had a decreasing trend following the increase in serum dilutions $(F=44.582, P<0.0001)$. There was also a clear correlation between cytotoxicity and culture time $(\mathrm{r}=0.917$, $P<0.01)$, and cytotoxicity showed an increasing trend with prolonged culture time $(F=33.420, P<0.01)$.

\section{Discussion}

Elastase is a trypsin-like serine protease that can hydrolyze the host's diverse tissue components (e.g., fibronectin, laminin, type IV collagen, elastin). The 

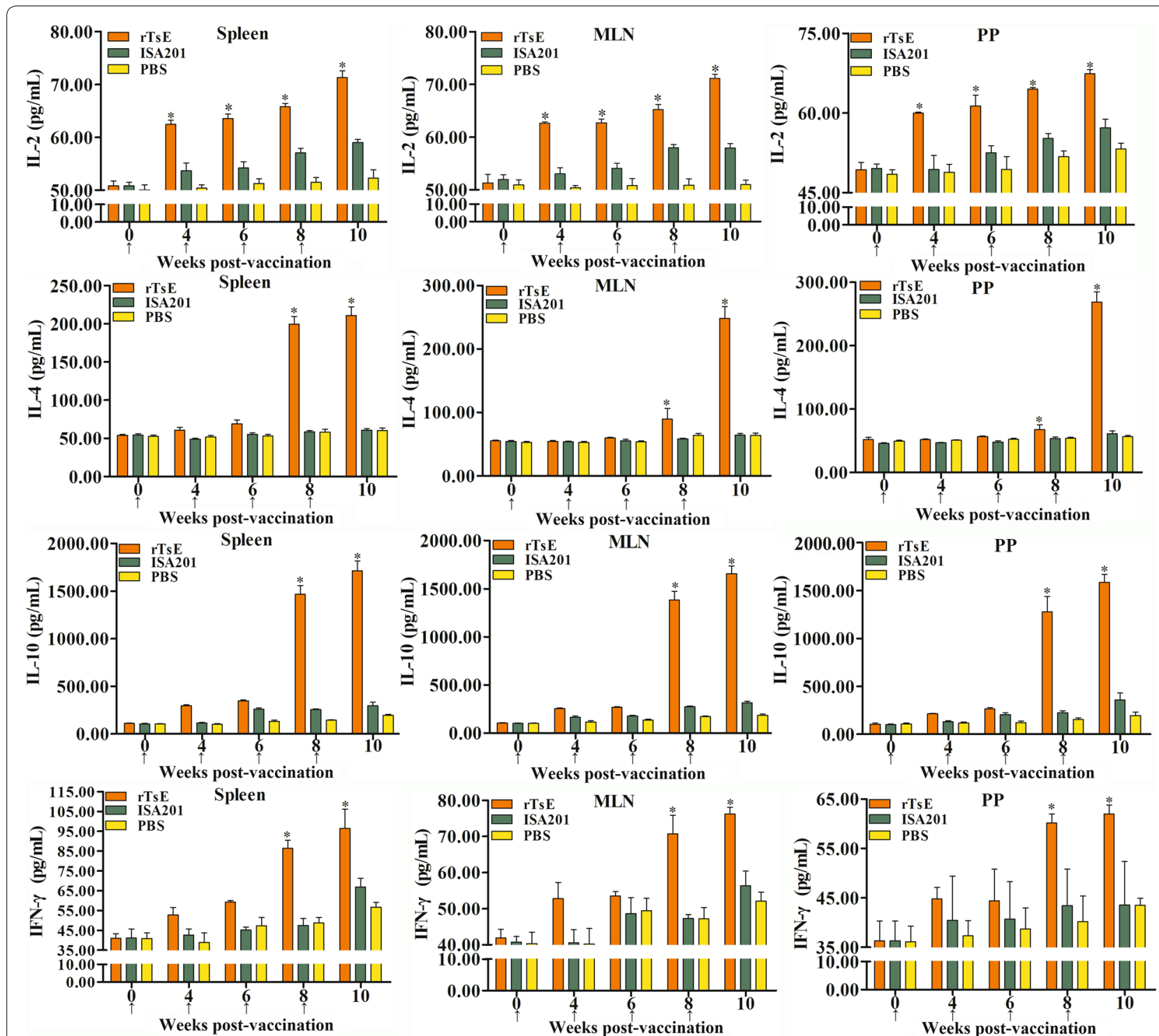

Figure 5 Cytokines secreted by the spleen, mesenteric lymph nodes (MLNs) and Peyer's patches (PPs) of mice vaccinated with rTsE at various times post-vaccination. The concentrations of four cytokines (IFN- $\gamma, \mathrm{IL}-2, \mathrm{LL}-4$, and IL-10) were determined in the supernatant after spleen, MLN and PP cells were stimulated by $10 \mu \mathrm{g} \mathrm{rTsE}$ for $72 \mathrm{~h}$. The values are shown as the mean \pm SD of ten animals/group. The vaccination time is indicated as an arrow $(\uparrow) .{ }^{*} P<0.0001$ relative to the ISA201 and PBS control groups.

elastases participate in parasite penetration, molting and digestion and may play a major role in worm intrusion of hosts [62]. In our previous study, TsE was cloned, expressed and identified, and it was likely a novel target molecule for preventive vaccines against $T$. spiralis infection. In this study, immunization of mice with the rTsE protein generated a specific serum antibody response against $r T s E$, and the anti-rTsE antibody IgG titer was 1:10 000, suggesting that rTsE had strong immunogenicity. Our results showed that anti-rTsE IgG from vaccinated mice recognized the native $\mathrm{TsE}$ at the cuticle, stichosome of this nematode, and intrauterine embryos of female AW. Subcutaneous vaccination with rTsE produced a systemic humoral immune response and significant local enteral mucosal sIgA responses. sIgA acts an important function in mucosal defense and might protect the intestinal epithelium from parasite intrusion [42, 63]. Anti-T. spiralis sIgA mediated intestinal adult expulsion from the gut, and passive transfer of the anti-Trichinella antibody IgA produced evident protection against larval challenge in mice [64]. 

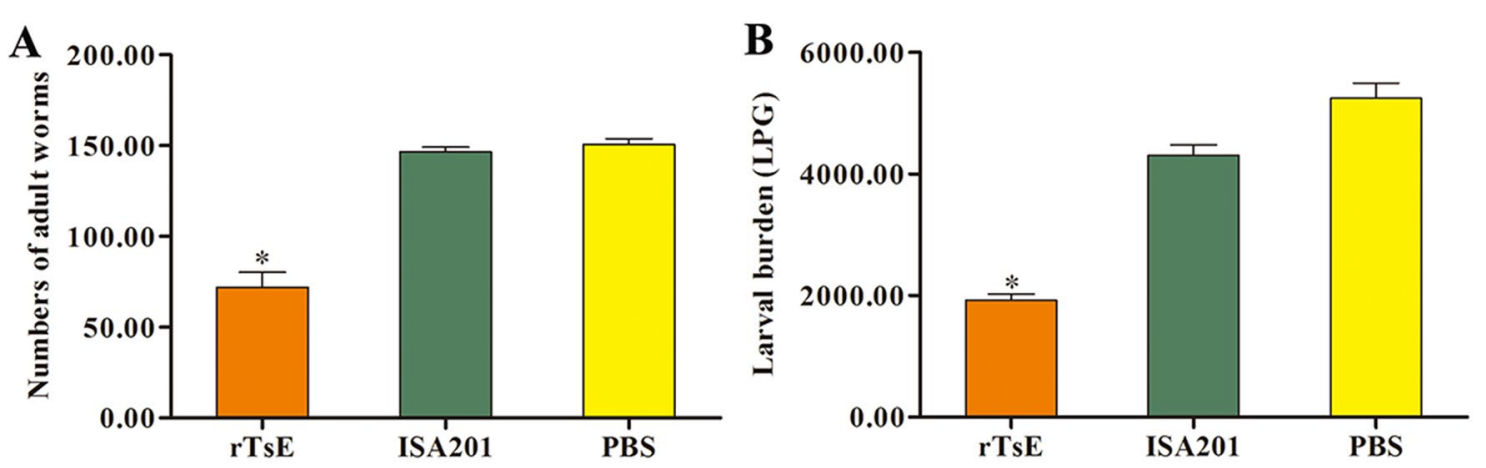

Figure 6 Immune protection efficacy of $\mathrm{rTsE}$ immunization following oral infection with $T$. spiralis larvae in a mouse model. A Intestinal adult worm burden; B Muscle larva burden (larvae per gram, lpg). The parasite burden is presented as the mean \pm SD from rTsE-vaccinated mice, only ISA201 adjuvant and PBS group $(n=10) .{ }^{*} P<0.0001$ compared to the ISA201 adjuvant and PBS groups.
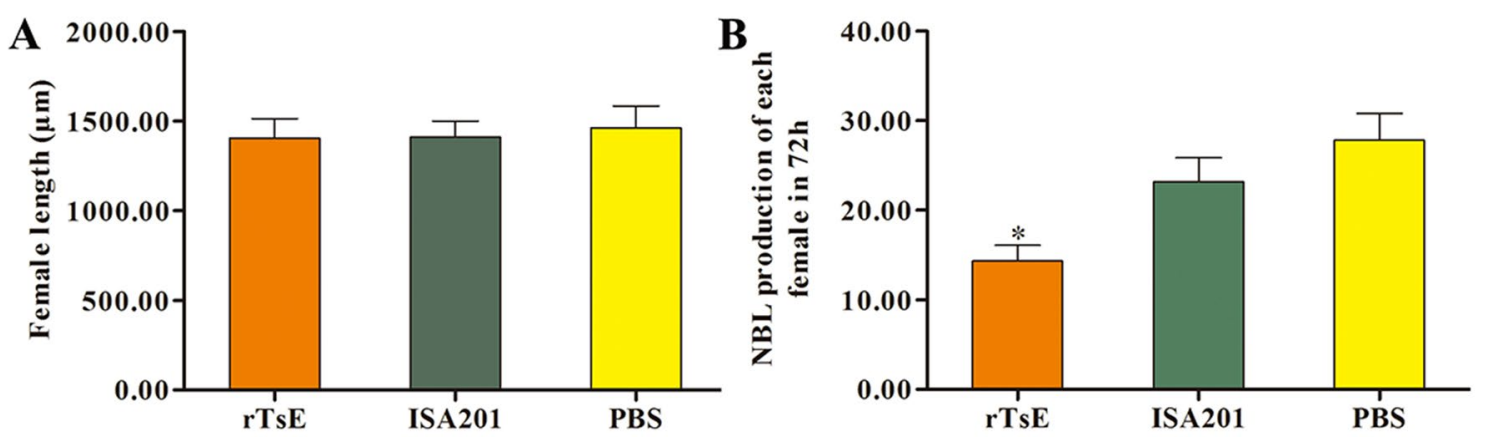

Figure 7 Length and fecundity of T. spiralis female adults from rTsE-vaccinated mice at 7 days following larval challenge $(n=10)$. a Female adult length; $\mathbf{b}$ Newborn larval production of each female in vitro for $72 \mathrm{~h}$.

Our results also indicated that subcutaneous immunization with $\mathrm{rTsE}$ induced the mixed Th1/Th2 response, as demonstrated by an obvious elevation of Th1 cytokines (IFN- $\gamma$, IL-2) and Th2 cytokines (IL-4, IL-10) after spleen, MLN and PP cells from immunized mice were stimulated with rTsE. The mixed Th1/Th2 response is crucial for immune protective efficacy against Trichinella infection [45]. In addition, the production of mucosal sIgA is Th2-dependent; in particular, IL-10 is a main cytokine that enhances the IgA response. In this study, the correlation of elevated enteral sIgA levels and high IL-10 levels demonstrate that the cytokine IL-10 enhances the enteral mucosal sIgA response.

Following $T$. spiralis challenge infection, the rTsEimmunized mice exhibited a $52.19 \%$ decrease in enteral adults at $7 \mathrm{dpi}$ and a $64.06 \%$ decrease in muscle larvae at $42 \mathrm{dpi}$. The worm burden decrease observed in the present work is similar to those of previous studies [26, 32, 54]. The immune protective effect may be due to the production of a high level of specific anti-TsE IgG antibody, which neutralized the hydrolyzing ability of elastase.
Anti-Trichinella IgG also binds to the cuticle of enteral stage worms and forms a cap-like immune complex in the parasite anterior end, which physically interdicts the worms' direct contact with enteral epithelia, blocking worm intrusion of enteral mucosa and impairing worm growth and development [65]. Anti-Trichinella antibody IgG also participated in damage and destruction of newborn larvae through an ADCC pattern [66]. To ascertain the cytotoxicity of anti-TsE antibodies, an ADCC assay was also conducted in this study. The results indicated that TsE-specific antibody facilitated macrophage adherence and damage to the NBL, and ADCC cytotoxicity was dose-dependent for anti-TsE antibodies.

Although the length of enteral female adults from immunized mice was not significantly different from those from the ISA 201 or PBS group, the female fecundity (e.g., the NBL production/female in vitro for $72 \mathrm{~h}$ ) was significantly inferior to that from ISA 201 or PBS control mice. Previous studies indicated that enteral sIgA suppressed the reproductive capacity of T. spiralis adult females [67]. Our results suggested that protective 

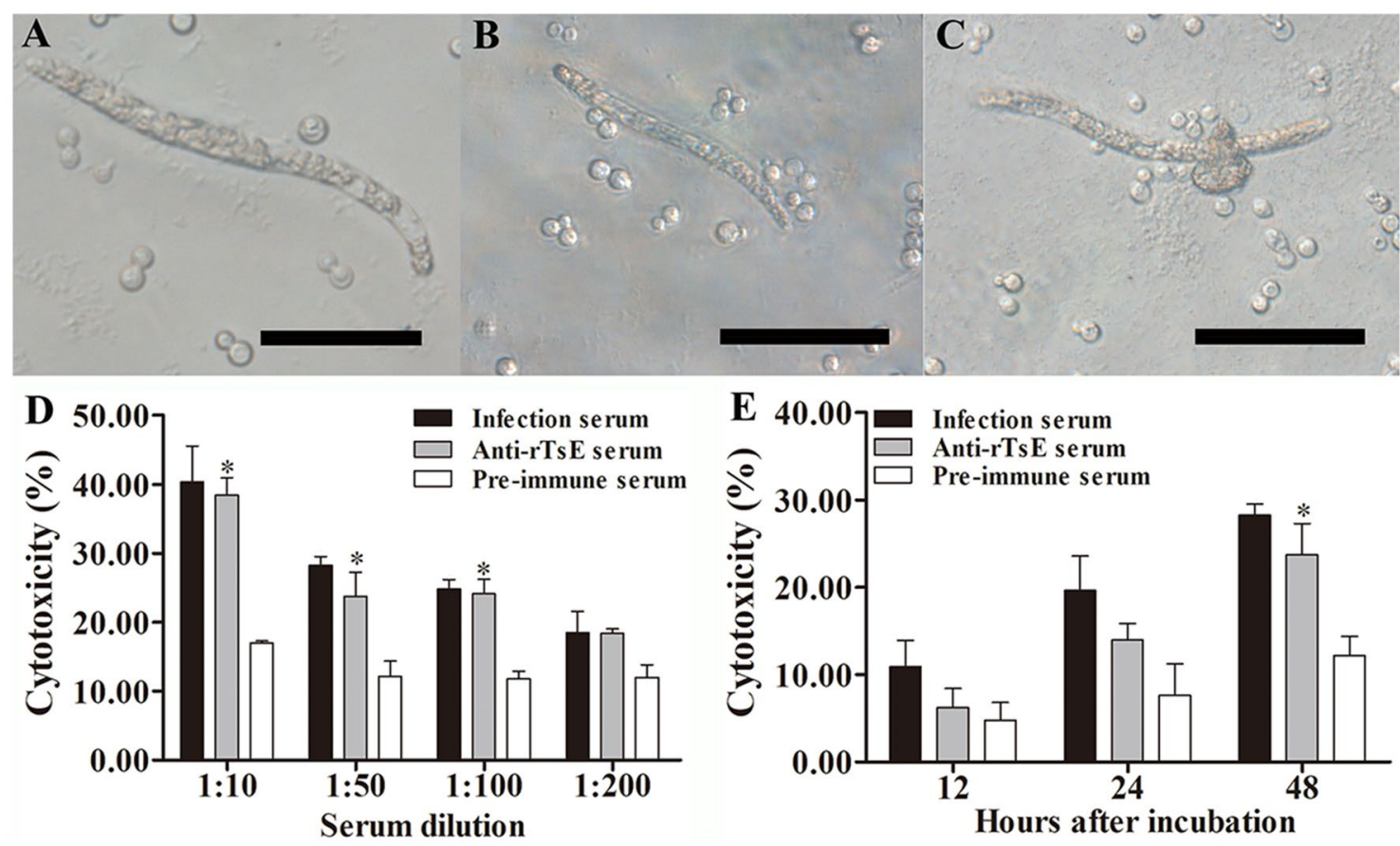

Figure 8 Killing effects of ADCC on T. spiralis NBL. The NBL were cocultivated with anti-rTsE serum and $2 \times 10^{5}$ mouse peritoneal exudate cells (PECs) at $37^{\circ} \mathrm{C}$ for 48 h. A Live NBL; B PEC adherence to NBL; C dead NBL. D Cytotoxicity was dose-dependent for anti-rTsE antibodies. E Cytotoxicity also increased with prolonged cultivation time. ${ }^{*} P<0.05$ compared with the preimmune serum group. Scale bars: $50 \mu \mathrm{m}$.

immunity induced by immunization with rTsE also depressed intestinal worm development and impaired the reproductive capacity of adult females $[10,43]$.

In recent years, some protein molecules from various T. spiralis lifecycle stages have been characterized and expressed, and their immune protection was also evaluated, such as paramyosin (Ts-Pmy) from an adult cDNA library [9], TspGST and fructose-1,6-bisphosphate aldolase (Ts-FBPA) from the $T$. spiralis draft genome with high expression at the ML stage [33, 68], Ts31 from the ML ES proteins [54], serine protease (TsSP) from IIL and ML surface proteins [55], and cathepsin B (TsCB) from the T. spiralis draft genome [56]. However, when these recombinant proteins were used for vaccinating mice, they exhibited only $36.2-53.50 \%$ ML reduction following T. spiralis challenge. In the present study, we ascertain the protective immunity induced by vaccination with a novel TsE protein. Since TsE is a secretory protein that is highly expressed at the T. spiralis intestinal invasive stage (IIL), TsE might be exposed early to the host's intestinal mucosa and elicit the local immune response. Our results indicated that vaccination with $\mathrm{rTsE}$ induced significantly high levels of TsE-specific sIgA, which might facilitate adult worm expulsion from the intestine [64]. The immune protection (64.06\% ML reduction) with this novel TsE vaccination was superior to those of the abovementioned other $T$. spiralis proteins as candidate vaccine target molecules. This study also established a foundation to develop polyvalent anti-T. spiralis vaccines in the future.

Trichinellosis principally results from the oral ingestion of infected animal meat. Trichinella is a multicellular enteral and tissue-lodging parasite that has a complicated lifecycle, and diverse Trichinella developmental phase worms have stage-specific antigens. Vaccination with a single Trichinella protein molecule or peptide merely elicited approximately $60 \%$ protection from larva challenge infection. In future studies, polyvalent vaccines should be developed and contain multiple protective antigenic epitopes from diverse T. spiralis developmental phases (IIL, AW, NBL and ML) to elicit both systemic/ enteral local humoral and cellular immune responses. To acquire full immune protection, ideal polyvalent vaccines must prevent Trichinella infection and block the development of clinical trichinellosis at various lifecycle phases: interrupting IIL larval invasion of enteral epithelia, blocking IIL larval development to the adult stage, dislodging adult worms from the guts, interdicting or impeding NBL generation from enteral residual adults, killing escaping NBL to prevent their migration in blood and larval encapsulation in skeletal muscles [36, 69]. Hence, oral polyvalent vaccines against different $T$. 
spiralis life cycle phases need to be developed to interrupt Trichinella infection transmission among domestic food animals [9].

In conclusion, our results showed that subcutaneous vaccination of mice with a novel rTsE produced a systemic Th1/Th2 mixed response and local enteral mucosal sIgA response. The vaccinated mice showed significant immune protection, as demonstrated by a $52.19 \%$ reduction in enteral adults and a $64.06 \%$ reduction in muscle larvae following $T$. spiralis larval challenge. The immune responses triggered by $\mathrm{rTsE}$ vaccination also inhibited enteral worm development and reduced the reproductive capacity of adult females. The results indicated that TsE might be considered a novel target molecule for anti- $T$. spiralis vaccines.

\section{Abbreviations}

ADCC: Antibody-dependent cell-mediated cytotoxicity; AW: Adult worms; BSA: Bovine serum albumin; ES: Excretion-secretion; IEC: Intestinal epithelial cells; IFT: Immunofluorescence test; IIL: Intestine infective larvae; Ipg: Larvae per gram; ML: Muscle larvae; MLN: Mesenteric lymph nodes; NBL: Newborn larvae; OPD: o-Phenylenediamine dihydrochloride; PECs: Peritoneal exudate cells; PP: Peyer's patches; rTsE: Recombinant TsE; slgA: Secretory IgA; TBST: TBS0.5\% Tween 20; TsE: T. spiralis elastase-1.

\section{Acknowledgements}

This study was supported by grants from the National Natural Science Foundation of China (U1704284 and 81971952).

\section{Authors' contributions}

$J C, Z Q W$, and $X L$ designed this study. XZZ, XYS, YB, YYS and CXH performed the experiments. XZZ, JC and ZQW drafted and revised the manuscript. All authors read and approved the final manuscript.

\section{Ethics approval and consent to participate}

This research was conducted in keeping with the National Guidelines for Experimental Animal Welfare (Minister of Science and Technology, the People's Republic of China, 2006). The animal experiment in this work was approved by the Institutional Life Science Ethics Committee, Zhengzhou University (No. SCXK 2017-0001).

\section{Competing interests}

The authors declare that they have no competing interests.

Received: 12 January 2020 Accepted: 3 March 2020

Published online: 14 March 2020

\section{References}

1. Pozio E (2007) World distribution of Trichinella spp. infections in animals and humans. Vet Parasitol 149:3-21

2. Cui J, Wang ZQ (2011) An epidemiological overview of swine Trichinellosis in China. Vet J 190:323-328

3. Cui J, Jiang P, Liu LN, Wang ZQ (2013) Survey of Trichinella infections in domestic pigs from northern and eastern Henan, China. Vet Parasitol 194:133-135

4. Jiang P, Zhang X, Wang LA, Han LH, Yang M, Duan JY, Sun GG, Qi X, Liu RD, Wang ZQ, Cui J (2016) Survey of Trichinella infection from domestic pigs in the historical endemic areas of Henan province, central China. Parasitol Res 115:4707-4709

5. Rostami A, Gamble HR, Dupouy-Camet J, Khazan H, Bruschi F (2017) Meat sources of infection for outbreaks of human Trichinellosis. Food Microbiol 64:65-71
6. Cui J, Wang ZQ, Xu BL (2011) The epidemiology of human Trichinellosis in China during 2004-2009. Acta Trop 118:1-5

7. Murrell KD, Pozio E (2011) Worldwide occurrence and impact of human Trichinellosis, 1986-2009. Emerg Infect Dis 17:2194-2202

8. Bai X, Hu X, Liu X, Tang B, Liu M (2017) Current research of Trichinellosis in China. Front Microbiol 8:1472

9. Gu Y, Sun X, Li B, Huang J, Zhan B, Zhu X (2017) Vaccination with a paramyosin-based multi-epitope vaccine elicits significant protective immunity against Trichinella spiralis infection in mice. Front Microbiol 8:1475

10. Liu P, Wang ZQ, Liu RD, Jiang P, Long SR, Liu LN, Zhang XZ, Cheng XC, Yu C, Ren HJ, Cui J (2015) Oral vaccination of mice with Trichinella spiralis nudix hydrolase DNA vaccine delivered by attenuated Salmonella elicited protective immunity. Exp Parasitol 153:29-38

11. Ren HJ, Cui J, Wang ZQ, Liu RD (2011) Normal mouse intestinal epithelial cells as a model for the in vitro invasion of Trichinella spiralis infective larvae. PLoS ONE 6:e27010

12. Liu RD, Wang ZQ, Wang L, Long SR, Ren HJ, Cui J (2013) Analysis of differentially expressed genes of Trichinella spiralis larvae activated by bile and cultured with intestinal epithelial cells using real-time PCR. Parasitol Res 112:4113-4120

13. Despommier DD (1998) How does Trichinella spiralis make itself at home? Parasitol Today 14:318-323

14. Long SR, Wang ZQ, Jiang P, Liu RD, Qi X, Liu P, Ren HJ, Shi HN, Cui J (2015) Characterization and functional analysis of Trichinella spiralis Nudix hydrolase. Exp Parasitol 159:264-273

15. Wang ZQ, Liu RD, Sun GG, Song YY, Jiang P, Zhang X, Cui J (2017) Proteomic analysis of Trichinella spiralis adult worm excretory-secretory proteins recognized by sera of patients with early Trichinellosis. Front Microbiol 8:986

16. Song YY, Wang LA, Na Ren H, Qi X, Sun GG, Liu RD, Jiang P, Zhang X, Cui J, Wang ZQ (2018) Cloning, expression and characterisation of a cysteine protease from Trichinella spiralis. Folia Parasitol (Praha) 65(2018):007

17. Xu J, Liu RD, Long SR, Jiang P, Zhang X, Cui J, Wang ZQ (2020) Characterization of a chymotrypsin-like enzyme from Trichinella spiralis and its facilitation on larva penetration of host's enteral epithelial cells. Res Vet Sci 128:1-8

18. Bolas-Fernandez F, Corral Bezara LD (2006) TSL-1 antigens of Trichinella: an overview of their potential role in parasite invasion, survival and serodiagnosis of trichinellosis. Res Vet Sci 81:297-303

19. Sofronic-Milosavljevic L, llic N, Pinelli E, Gruden-Movsesijan A (2015) Secretory productsof Trichinella spiralis muscle larvae and immunomodulation: implication for autoimmune diseases, allergies, and malignancies. J Immunol Res 2015:523875

20. Liu RD, Jiang P, Wen H, Duan JY, Wang LA, Li JF, Liu CY, Sun GG, Wang ZQ, Cui J (2016) Screening and characterization of early diagnostic antigens in excretory-secretory proteins from Trichinella spiralis intestinal infective larvae by immunoproteomics. Parasitol Res 115:615-622

21. Liu RD, Qi X, Sun GG, Jiang P, Zhang X, Wang LA, Liu XL, Wang ZQ, Cui $J$ (2016) Proteomic analysis of Trichinella spiralis adult worm excretorysecretory proteins recognized by early infection sera. Vet Parasitol 231:43-46

22. Wang ZQ, Wang L, Cui J (2012) Proteomic analysis of Trichinella spiralis proteins in intestinal epithelial cells after culture with their larvae by shotgun LC-MS/MS approach. J Proteomics 75:2375-2383

23. Wang L, Wang ZQ, Cui J (2013) Proteomic analysis of the changed proteins of Trichinella spiralis infective larvae after co-culture in vitro with intestinal epithelial cells. Vet Parasitol 194:160-163

24. Liu RD, Cui J, Liu XL, Jiang P, Sun GG, Zhang X, Long SR, Wang L, Wang ZQ (2015) Comparative proteomic analysis of surface proteins of Trichinella spiralis muscle larvae and intestinal infective larvae. Acta Trop 150:79-86

25. Nagano I, Wu Z, Takahashi Y (2009) Functional genes and proteins of Trichinella spp. Parasitol Res 104:197-207

26. Wang B, Wang ZQ, Jin J, Ren HJ, Liu LN, Cui J (2013) Cloning, expression and characterization of a Trichinella spiralis serine protease gene encoding a $35.5 \mathrm{kDa}$ protein. Exp Parasitol 134:148-154

27. Song YY, Zhang Y, Ren HN, Sun GG, Qi X, Yang F, Jiang P, Zhang X, Cui J, Wang ZQ (2018) Characterization of a serine protease inhibitor from Trichinella spiralis and its participation in larval invasion of host's intestinal epithelial cells. Parasit Vectors 11:499 
28. Mitreva M, Jasmer DP, Zarlenga DS, Wang Z, Abubucker S, Martin J, Taylor $C M$, Yin Y, Fulton L, Minx P, Yang SP, Warren WC, Fulton RS, Bhonagiri V, Zhang X, Hallsworth-Pepin K, Clifton SW, McCarter JP, Appleton J, Mardis ER, Wilson RK (2011) The draft genome of the parasitic nematode Trichinella spiralis. Nat Genet 43:228-235

29. Hu CX, Jiang P, Yue X, Zeng J, Zhang XZ, Song YY, Liu RD, Zhang $X$, Wang ZQ, Cui J (2020) Molecular characterization of a Trichinella spiralis elastase-1 and its potential as a diagnostic antigen for trichinellosis. Parasit Vectors 13:97

30. Xu J, Bai X, Wang LB, Shi HN, van der Giessen JWB, Boireau P, Liu MY, Liu XL (2017) Influence of adjuvant formulation on inducing immune response in mice immunized with a recombinant serpin from Trichinella spiralis. Parasite Immunol 39:e12437

31. Wang ZQ, Li LZ, Jiang P, Liu LN, Cui J (2012) Molecular identification and phylogenetic analysis of Trichinella isolates from different provinces in mainland China. Parasitol Res 110:753-757

32. Li JF, Guo KX, Qi X, Lei JJ, Han Y, Yan SW, Jiang P, Yu C, Cheng XC, Wang ZQ, Cui J (2018) Protective immunity against Trichinella spiralis in mice elicited by oral vaccination with attenuated Salmonella-delivered TsSP1.2 DNA. Vet Res 49:87

33. Liu CY, Song YY, Ren HN, Sun GG, Liu RD, Jiang P, Long SR, Zhang X, Wang ZQ, Cui J (2017) Cloning and expression of a Trichinella spiralis putative glutathione S-transferase and its elicited protective immunity against challenge infections. Parasit Vectors 10:448

34. Long SR, Wang ZQ, Liu RD, Liu LN, Li LG, Jiang P, Zhang X, Zhang ZF, Shi HN, Cui J (2014) Molecular identification of Trichinella spiralis nudix hydrolase and its induced protective immunity against trichinellosis in BALB/C mice. Parasit Vectors 7:600

35. Cui J, Wang L, Sun GG, Liu LN, Zhang SB, Liu RD, Zhang X, Jiang P, Wang ZQ (2015) Characterization of a Trichinella spiralis $31 \mathrm{kDa}$ protein and its potential application for the serodiagnosis of trichinellosis. Acta Trop 142:57-63

36. Song $Y Y$, Zhang $Y$, Yang $D$, Ren HN, Sun GG, Jiang $P$, Liu RD, Zhang $X$, Cui J, Wang ZQ (2018) The immune protection pnduced by a serine protease inhibitor from the foodborne parasite Trichinella spiralis. Front Microbiol 9:1544

37. Sun GG, Lei JJ, Guo KX, Liu RD, Long SR, Zhang X, Jiang P, Cui J, Wang ZQ (2019) Primary assessment of a T. spiralis putative serine protease for early serological detection of Trichinella infection. Trop Biomed 36:792-802

38. Li LG, Wang ZQ, Liu RD, Yang X, Liu LN, Sun GG, Jiang P, Zhang X, Zhang GY, Cui J (2015) Trichinella spiralis: low vaccine potential of glutathione S-transferase against infections in mice. Acta Trop 146:25-32

39. Liu LN, Wang ZQ, Zhang X, Jiang P, Qi X, Liu RD, Zhang ZF, Cui J (2015) Characterization of Spirometra erinaceieuropaei plerocercoid cysteine protease and potential application for serodiagnosis of sparganosis. PLoS Negl Trop Dis 9:e0003807

40. Bermudez-Cruz RM, Fonseca-Linan R, Grijalva-Contreras LE, MendozaHernandez G, Ortega-Pierres MG (2016) Proteomic analysis and immunodetection of antigens from early developmental stages of Trichinella spiralis. Vet Parasitol 231:22-31

41. Qi X, Han Y, Jiang P, Yue X, Ren HN, Sun GG, Long SR, Yu C, Cheng XC, Cu J, Wang ZQ (2018) Oral vaccination with Trichinella spiralis DNase II DNA vaccine delivered by attenuated Salmonella induces a protective immunity in BALB/C mice. Vet Res 49:119

42. Liu P, Cui J, Liu RD, Wang M, Jiang P, Liu LN, Long SR, Li LG, Zhang SB, Zhang XZ, Wang ZQ (2015) Protective immunity against Trichinella spiralis infection induced by $T s N d$ vaccine in mice. Parasit Vectors 8:185

43. Sun GG, Lei JJ, Ren HN, Zhang Y, Guo KX, Long SR, Liu RD, Jiang P, Wang ZQ, Cui J (2019) Intranasal immunization with recombinant Trichinella spiralis serine protease elicits protective immunity in BABL/c mice. Exp Parasitol 201:1-10

44. Liu LN, Jing FJ, Cui J, Fu GY, Wang ZQ (2013) Detection of circulating antigen in serum of mice infected with Trichinella spiralis by an IgY-IgM mAb sandwich ELISA. Exp Parasitol 133:150-155

45. Pompa-Mera EN, Arroyo-Matus P, Ocana-Mondragon A, Gonzalez-Bonilla CR, Yepez-Mulia L (2014) Protective immunity against enteral stages of Trichinella spiralis elicited in mice by live attenuated Salmonella vaccine that secretes a 30-mer parasite epitope fused to the molecular adjuvant C3d-P28. Res Vet Sci 97:533-545

46. Sun GG, Song YY, Jiang P, Ren HN, Yan SW, Han Y, Liu RD, Zhang X, Wang ZQ, Cui J (2018) Characterization of a Trichinella spiralis putative serine protease. Study of its potential as sero-diagnostic tool. PLoS Negl Trop Dis 12:e0006485

47. Jiang P, Wang ZQ, Cui J, Zhang X (2012) Comparison of artificial digestion and Baermann's methods for detection of Trichinella spiralis pre-encapsulated larvae in muscles with low-level infections. Foodborne Pathog Dis 9:27-31

48. Yang W, Li LG, Liu RD, Sun GG, Liu CY, Zhang SB, Jiang P, Zhang X, Ren HJ, Wang ZQ, Cui J (2015) Molecular identification and characterization of Trichinella spiralis proteasome subunit beta type-7. Parasit Vectors 8:18

49. Zhang Y, Wang Z, Li L, Cui J (2013) Molecular characterization of Trichinella spiralis aminopeptidase and its potential as a novel vaccine candidate antigen against trichinellosis in BALB/c mice. Parasit Vectors 6:246

50. Liu CY, Ren HN, Song YY, Sun GG, Liu RD, Jiang P, Long SR, Zhang X, Wang ZQ, Cui J (2018) Characterization of a putative glutathione S-transferase of the parasitic nematode Trichinella spiralis. Exp Parasitol 187:59-66

51. XU J, Yang F, Yang DQ, Jiang P, Liu RD, Zhang X, Cui J, Wang ZQ (2018) Molecular characterization of Trichinella spiralis galectin and its participation in larval invasion of host's intestinal epithelial cells. Vet Res 49:79

52. Dea-Ayuela MA, Rama-Iniguez S, Bolas-Fernandez F (2006) Vaccination of mice against intestinal Trichinella spiralis infections by oral administration of antigens microencapsulated in methacrilic acid copolymers. Vaccine 24:2772-2780

53. Cui J, Ren HJ, Liu RD, Wang L, Zhang ZF, Wang ZQ (2013) Phage-displayed specific polypeptide antigens induce significant protective immunity against Trichinella spiralis infection in BALB/c mice. Vaccine 31:1171-1177

54. Ren HN, Guo KX, Zhang Y, Sun GG, Liu RD, Jiang P, Zhang X, Wang L, Cui J, Wang ZQ (2018) Molecular characterization of a $31 \mathrm{kDa}$ protein from Trichinella spiralis and its induced immune protection in BALB/C mice. Parasit Vectors 11:625

55. Sun GG, Ren HN, Liu RD, Song YY, Qi X, Hu CX, Yang F, Jiang P, Zhang X, Wang ZQ, Cui J (2018) Molecular characterization of a putative serine protease from Trichinella spiralis and its elicited immune protection. Vet Res 49:59

56. Cui J, Han Y, Yue X, Liu F, Song YY, Yan SW, Lei JJ, Zhang X, Jiang P, Wang ZQ (2019) Vaccination of mice with a recombinant novel cathepsin B inhibits Trichinella spiralis development, reduces the fecundity and worm burden. Parasit Vectors 12:581

57. Wang ZQ, Zhang SB, Jiang P, Liu RD, Long SR, Zhang X, Ren HJ, Cui J (2015) The siRNA-mediated silencing of Trichinella spiralis nudix hydrolase results in reduction of larval infectivity. Parasitol Res 114:3551-3557

58. Wang J, Jiang Y, Yang W, Shi C, Huang H, Sun H, Liu G, Wang C, Yang G, Cai Y (2018) Vaccination with DNA encoding ES 43-kDa/45-kDa antigens significantly reduces Trichinella spiralis infection in mice. Res Vet Sci 120:4-10

59. Zhang $S B$, Jiang $P$, Wang ZQ, Long $S R$, Liu RD, Zhang $X$, Yang W, Ren $H J$, Cui J (2016) DsRNA-mediated silencing of Nudix hydrolase in Trichinella spiralis inhibits the larval invasion and survival in mice. Exp Parasitol 162:35-42

60. Yang F, Yang DQ, Song YY, Guo KX, Li YL, Long SR, Jiang P, Cui J, Wang ZQ (2019) In vitro silencing of a serine protease inhibitor suppresses Trichinella spiralis invasion, development, and fecundity. Parasitol Res 118:2247-2255

61. Qi X, Yue X, Han Y, Jiang P, Yang F, Lei JJ, Liu RD, Zhang X, Wang ZQ, Cui J (2018) Characterization of two Trichinella spiralis adult-specific DNase II and their capacity to induce protective immunity. Front Microbiol 9:2504

62. El-Faham MH, Wheatcroft-Francklow KJ, Price HP, Sayers JR, Doenhoff MJ (2017) Schistosoma mansoni cercarial elastase (SmCE): differences in immunogenic properties of native and recombinant forms. Parasitology 144:1356-1364

63. Martinez-Gomez F, Santiago-Rosales R, Ramon Bautista-Garfias C (2009) Effect of Lactobacillus casei Shirota strain intraperitoneal administration in CD1 mice on the establishment of Trichinella spiralis adult worms and on IgA anti-T. spiralis production. Vet Parasitol 162:171-175

64. Inaba T, Sato H, Kamiya H (2003) Impeded establishment of the infective stage of Trichinella in the intestinal mucosa of mice by passive transfer of an IgA monoclonal antibody. J Vet Med Sci 65:1227-1231

65. McVay CS, Bracken P, Gagliardo LF, Appleton J (2000) Antibodies to tyvelose exhibit multiple modes of interference with the epithelial niche of Trichinella spiralis. Infect Immun 68:1912-1918

66. Cui J, Li LG, Jiang P, Liu RD, Yang X, Liu LN, Liu P, Zhang SB, Wang ZQ (2015) Biochemical and functional characterization of the glutathione S-transferase from Trichinella spiralis. Parasitol Res 114:2007-2013 
67. Robinson K, Bellaby T, Wakelin D (1995) Oral and parenteral vaccination against Trichinella spiralis infections in high-and low-responder mice. Int J Parasitol 25:989-992

68. Yang Y, Bai X, Li C, Tong M, Zhang P, Cai W, Liu X, Liu M (2019) Molecular characterization of fructose-1, 6-bisphosphate aldolase from Trichinella spiralis and its potential in inducing immune protection. Front Cell Infect Microbiol 9:122

69. Ortega-Pierres G, Vaquero-Vera A, Fonseca-Linan R, Bermudez-Cruz RM, Arguello-Garcia R (2015) Induction of protection in murine experimental models against Trichinella spiralis: an up-to-date review. J Helminthol 89:526-539

\section{Publisher's Note}

Springer Nature remains neutral with regard to jurisdictional claims in published maps and institutional affiliations.
Ready to submit your research? Choose BMC and benefit from:

- fast, convenient online submission

- thorough peer review by experienced researchers in your field

- rapid publication on acceptance

- support for research data, including large and complex data types

- gold Open Access which fosters wider collaboration and increased citations

- maximum visibility for your research: over $100 \mathrm{M}$ website views per year

At BMC, research is always in progress.

Learn more biomedcentral.com/submissions 